\title{
Perancangan Wacinwa: Sang Manggalayudha
}

\author{
Aneng Kiswantoro \\ Jurusan Pedalangan, Fakultas Seni Pertunjukan, Institut Seni Indonesia Yogyakarta \\ Email: anengkiswantoro@gmail.com
}

\begin{abstract}
The purpose of this design work is to make Wacinwa dolls that are tailored to the interests and needs of the designer in the show. The making of puppets is motivated by the constraints in the availability of puppets for staging. Meanwhile, Wacinca is only owned by Yogyakarta's Sonobudoyo Museum. Besides the Wacinwa doll, the collection of Sonobudoyo Museum is too small, its head is detached from the body, and it is difficult to move. The characters made are figures in working on the Wacinwa story entitled Sang Manggalayuda. The Hawkins (1991) method of designing stages is used in this work. The stages are the first stage of exploration, namely setting themes, ideas, and titles of works and thinking, imagining, feeling, and searching in order to interpret ideas and ideas. The second stage is the experimentation stage, which is trying to choose, differentiate, consider in order to find harmony and find integrity and unity in various experiments. The last stage is the formation stage, which is to determine the form of design by combining the symbols of the results of the trials conducted. After the figures of the figures are made, the designer tries to pour into the skin media, sculpted, and given coloring just like the process of making shadow puppets (purwa). The Wacinwa replica made includes puppets from Sie Jin Kwie and Khai Sou Bun. These puppets are the result of the interpretation of the designer based on the shape of the puppet collection of Sonobudoyo Museum and images in Sie Djin Koei Tjeng Tang's comic works by Siaw Tik Kwie (Oto Suastika).
\end{abstract}

Keywords: Wacinwa; replica; Sie Jin Kwie; Khai Sou Bun

\begin{abstract}
Abstrak
Tujuan karya perancangan ini adalah membuat boneka Wacinwa yang disesuaikan dengan kepentingan dan kebutuhan si perancang dalam pertunjukan. Pembuatan wayang dilatarbelakangi oleh adanya kendala dalam hal ketersediaan wayang untuk pementasan. Sementara ini Wacinca hanya dimiliki oleh Museum Sonobudoyo Yogyakarta. Selain itu boneka Wacinwa koleksi Museum Sonobudoyo ukurannya terlalu kecil, kepalanya terlepas dari badan, dan sulit digerakkan. Tokoh-tokoh yang dibuat adalah tokoh dalam garap cerita Wacinwa berjudul Sang Manggalayuda. Metode Hawkins (1991) tentang tahap-tahap merancang digunakan dalam karya ini. Adapun tahapan tersebut adalah pertama tahap eksplorasi, yaitu menetapkan tema, ide, dan judul karya serta berpikir, berimajinasi, merasakan, dan mencari dalam rangka menafsirkan ide dan gagasan. Tahap kedua adalah tahap eksperimentasi, yaitu mencoba untuk memilih, membedakan, mempertimbangkan dalam rangka mencari keharmonisan dan menemukan integritas serta kesatuan dalam berbagai percobaan. Tahap terakhir adalah tahap pembentukan, yaitu menentukan bentuk perancangan dengan menggabungkan simbol-simbol hasil dari uji coba yang dilakukan. Setelah gambar tokoh-tokoh tersebut jadi, perancang mencoba untuk menuangkan ke dalam
\end{abstract}


media kulit, dipahat, dan diberi pewarnaan seperti halnya proses pembuatan wayang kulit (purwa). Replika Wacinwa yang dibuat antara lain wayang tokoh Sie Jin Kwie dan Khai Sou Bun. Wayang-wayang ini merupakan hasil interpretasi perancang berdasarkan bentuk wayang koleksi Museum Sonobudoyo dan gambar dalam komik Sie Djin Koei Tjeng Tang karya Siaw Tik Kwie (Oto Suastika).

Kata kunci: Wacinwa; replika; Sie Jin Kwie; Khai Sou Bu

\section{Pendahuluan}

Pada tanggal 3-10 Oktober 2014 Museum Negeri Sonobudoyo bekerjasama dengan Dinas Kebudayaan Daerah Istimewa Yogyakarta mengadakan pameran Wayang Cina Jawa (Wacinwa). Dalam pameran Wayang Cina Jawa tersebut diselenggarakan juga pergelaran Wacinwa. Saat itu perancang mendapat kesempatan untuk mementaskan Wacinwa pada tanggal 9 Oktober 2014. Pergelaran Wacinwa Oktober 2014 ini kiranya dapat dikatakan merupakan kebangkitan kembali Wacinwa setelah tertidur beberapa lama yaitu semenjak meninggalnya Gan Thwan Sing tahun 1967.

Wayang Cina Jawa atau disebut Wacinwa lahir pada tahun 1925 dibidani oleh seorang pranakan Tionghoa bernama Gan Thwan Sing. Angka tahun pembuatan ini dapat ditemui di dalam Wacinwa yang berbentuk gunungan, koleksi Dr. Walter Angst di Uberlingen, Bodensee, Jerman, yang bertuliskan: dibuat oleh Gan Thwan Sing, 1925, Yogyakarta, (Prasetya, 2014: 9).

Pakeliran atau pertunjukan Wacinwa merupakan perpaduan serasi dua aspek seni dari latar belakang yang berbeda. Aspek pertama adalah kesenian pakeliran Jawa, dan yang kedua adalah ceritacerita legenda Cina. Kedua aspek inilah yang menginspirasi Gan Thwan Sing untuk menyatukannya ke dalam karya seni yang bisa dipertunjukkan. Dari penyatuan kedua aspek tersebut muncullah sebuah pertunjukan Wacinwa yang pergelarannya mengacu pada pakeliran tradisi Yogyakarta pada umumnya. Pertunjukan Wacinwa menggunakan perangkat pakeliran Jawa yaitu menggunakan gamelan slendro berikut pengrawit dan sinden serta menggunakan kelir, simpingan, bléncong, kothak, cempala dan lainnya. Idiom-idiom pakeliran jangkep Jawa khususnya Yogyakarta, seperti janturan, kombangan, sulukan, sendhon, pathetan, ada-ada, pocapan, kandha, cariyos dan lainnya juga digunakan dalam buku lakon Wacinwa yang ditulis oleh Gan Thwan Sing (...). Perbedaannya terletak pada penulisan nama-nama tokoh wayang, kerajaan, dan tempat yang semuanya disesuaikan dengan cerita yang dipaparkan. Karena cerita Wacinwa mengambil cerita folklore Cina maka penulisannya lebih ke logat Cina, (Soelarto dan Albiladiyah, 1980: 15-16).

Seperti telah dikemukakan di depan bahwa perancang diberi kesempatan untuk mempergelarkan Wayang Cina Jawa setelah hampir setengah abad pertunjukan Wacinwa tidak pernah dipergelarkan lagi tepatnya semenjak meninggalnya Gan Thwan Sing tahun 1967. Usai pergelaran, perancang mendapat apresiasi dari banyak kalangan, karena dianggap berhasil menghadirkan kembali Wacinwa yang sekian lama tertidur. Misalnya pada tahun baru Imlek 2556 (2015 M) perancang mendapatkan beberapa tawaran untuk mementaskan Wacinwa di Semarang, Komunitas Keturunan Tionghoa di Yogyakarta, dan Festival Budaya Tionghoa di Ketandan, Yogyakarta. Tawaran mempergelarkan Wacinwa di Semarang dan Komunitas Keturunan Tionghoa di Yogyakarta tidak dapat dipenuhi karena tidak mendapatkan ijin peminjaman wayang dari Museum Sonobudoyo. Sedangkan tawaran pentas dalam acara Festival Kebudayaan Tionghoa di Ketandan dapat dipenuhi karena mendapatkan ijin peminjaman wauyang dari Museum Sonobudoyo. Oleh karena itu pertunjukan Wacinwa di Ketandan dapat dilaksanakan tepatnya tanggal 5 Maret 2015. Pertunjukan Wacinwa di Ketandan mendapat perhatian dan tanggapan yang positif dari masyarakat pranakan Tionghoa maupun pemerintah daerah. Banyak di antara mereka yang menghubungi perancang untuk mempergelarkan Wacinwa.

Ada satu catatan yang sangat penting dari pengalaman perancang ketika mempergelarkan Wacinwa berhubungan dengan bentuk boneka 
Wacinwa. Seperti dikatakan di muka bahwa boneka Wacinwa yang digunakan dalam beberapa kali pertunjukan merupakan koleksi Museum Sonobudoyo. Boneka Wacinwa koleksi Museum Sonobudoyo mempunyai tinggi rata-rata sekitar 35 $\mathrm{cm}$, dan wayang yang paling tinggi hanya sekitar $68 \mathrm{~cm}$. Hal ini jauh berbeda dengan wayang kulit Jawa karena tinggi wayang kulit Jawa bisa sampai 1 meter lebih. Namun demikian Wacinwa karya Gan Thwan Sing ini mempunya keunikan tersendiri. Keunikan tersebut antara lain kepala wayang dan badan dibuat terpisah, sedangkan gapit penyangga wayang hanya sampai di leher wayang. Untuk menyambungkan kepala dan badan wayang, biasanya diikat atau dijahit dengan benang. Hal ini dilakukan supaya kepala wayang tidak sampai terlepas jika dimainkan. Dengan demikian kepala wayang dan badan juga bisa diganti satu ke yang lain tentunya disesuaikan dengan konsep tokoh yang akan dimunculkan. Kebanyakan boneka Wacinwa tidak memakai palemahan seperti pada wayang kulit Jawa. Palemahan adalah bentuk asesoris penyambung kedua kaki wayang yang berwarna merah atau hitam. Wacinwa tidak memakai palemahan mungkin hal ini karena boneka Wacinwa relatif kecil sehingga boneka wayang tetap kuat meskipun tidak memakai palemahan. Secara bentuk boneka Wacinwa sangat menarik terutama busana dan asesorisnya yang semuanya bercorakkan gaya Cina klasik. Dalam busana Wacinwa dilukiskan Pat Kua, bunga Lotus, pagoda, burung Hong, bangau, ikan, Liong dan lainnya sehingga jika dilihat tampak indah dan menarik (Prasetya, 2014: 10-11).

Dari paparan di atas kiranya dapat ditarik dua masalah penting dalam pementasan Wacinwa. Pertama, di Yogyakarta Wayang Cina Jawa merupakan artefak koleksi Museum Sonobudoyo sehingga tidak dapat sewaktu-waktu dipinjam, dengan demikian tidak semua tawaran pentas dapat dipenuhi karena tidak adanya boneka Wacinwa. Kedua, bentuk boneka yang kecil, gapit hanya sampai di leher, kepala yang sering diganti-ganti menyebabkan wayang sulit digerakkan dan juga rentan rusak.

Berpijak dari masalah itu perancang tergerak untuk merevitalisasi dan mengembangkan karya Wacinwa. Dalam karya ini perancang membuat tokoh-tokoh boneka Wacinwa yang terbingkai dalam garap cerita yang mengisahkan kejayaan tokoh Sie Jin Kwei. Perancangan ini diharapkan dapat menghasilkan replika boneka Wacinwa yang telah disempurnakan sehingga mudah digerakkan.

\section{Metode Perancangan}

Dalam rangka perancangan karya dibutuhkan langkah-langkah sistematis untuk memperlancar proses serta keberhasilan dalam mencapai sasaran yang akan dituju. Hawkins (1991) mengatakan bahwa untuk mencapai sasaran tersebut ada tiga tahap yang harus dilakukan yaitu: 1) eksplorasi, yaitu menetapkan tema, ide, dan judul karya serta berpikir, berimajinasi, merasakan dan mencari dalam rangka menafsirkan ide dan gagasan. Perancangan ini diberi judul Perancangan Wacinwa. Untuk mewujudkan perancangan ini dilakukan pencarian dan identifikasi tokoh-tokoh Wacinwa koleksi Sonobudoyo sesuai dengan cerita yang akan disampaikan. Untuk menggarap cerita ini perancang juga mencoba untuk mengidentifikasi cerita komik Sie Djin Koei Tjeng Tang karya Siaw Tik Kwie (1983) mulai dari jilid 1 sampai jilid 5. 2) Eksperimentasi, yaitu mencoba untuk memilih, membedakan, mempertimbangkan dalam rangka mencari keharmonisan dan menemukan integritas seta kesatuan dalam berbagai percobaan. Di dalam tahap kedua ini perancang mencoba menghubungkan berbagai temuan adegan dalam komik yang dianggap penting untuk dirangkai menjadi satu rangkaian cerita. Dalam merangkai cerita ini perancang membuat kesimpulan bahwa cerita yang akan digarap adalah cerita yang menonjolkan perjalanan tokoh Sie Jin Kwei dalam menyelesaikan setiap tugasnya mulai dari awal menjadi seorang prajurit di kerajaan Tong Thai Cong sampai diangkat menjadi Raja Muda Peng Lian Ong. Kisah perjalanan Sie Jin Kwei ini akan diberi judul Sang Manggalayuda. Setelah menentukan garapan cerita, perancang mencoba untuk mengidentifikasi tokohtokoh yang akan dimunculkan. Dalam tahapan ini dilakukan ekplorasi tokoh Wacinwa dan membuat beberapa gambar tokoh Wacinwa sesuai tokoh dalam cerita. 3) Pembentukan, yaitu menentukan bentuk perancangan dengan menggabungkan simbol-simbol hasil dari uji coba yang dilakukan. Setelah gambar tokoh-tokoh tersebut jadi, perancang mencoba untuk menuangkan ke dalam media 
kulit, dipahat, dan diberi pewarnaan seperti halnya proses pembuatan wayang kulit (purwa).

\section{Proses Pembuatan Tokoh Wayang}

Seperti telah dikemukakan bahwa tujuan karya ini adalah menghasilkan replika boneka Wacinwa yang disempurnakan sehingga mudah digerakkan. Boneka Wacinwa yang dibuat adalah tokoh-tokoh dalam garap cerita yang mengisahkan kejayaan tokoh Sie Jin Kwei.

Sie Jin Kwei merupakan cerita dari Cina yang sangat terkenal. Cerita sejarah ini disusun oleh Lo Kuan Chung dalam bentuk karya sastra pada pertengahan Dinasti Yuan sampai awal Dinasti Ming. Cerita Sie Jin Kwei berlatar belakang jaman dinasti Thang atau Thong di bawah pemerintahan Kaisar Thang Thai Chung sekitar 627-649 M, yaitu terjadinya perang besar antara Tiongkok dengan Kaoli, salah satu negara yang terletak di Semenanjung Korea pada masa lalu. Dalam kisah ini yang paling menjadi sorotan adalah seorang panglima besar gagah perkasa dari Tiongkok ketika menyerbu Negara Kaoli. Panglima tersebut bernama Sie Jin Kwei.

Dalam perkembangannya cerita Sie Jin Kwei juga mulai dikenal di Indonesia. Cerita ini dipopulerkan oleh masyarakat Cina yang melakukan urban dan menetap di Indonesia. Pada tahun 1952 redaktur majalah Star Weekly yang bernama Tan Hian Lay dan Auwyong Peng Kun bekas pemimpin umum harian Kompas, meminta salah seorang yang bernama Siauw Tik Kwei atau disebut Oto Suastika untuk melukis cerita bergambar dengan cerita Sie Jin Kwei. Dalam mebuat buku ini Oto Suastika dibantu oleh temannya yang bernama Herry Ashari sebagai pembuat sampul muka dan lay out dan Drs. Aggi Tjetje Sm. Hk. sebagai penyempurna tata bahasa dan ejaan (Aggi Tjetje dkk., 1983).

Dalam pembuatan tokoh-tokoh Wayang ini perancang mencoba mengekplorasi gambar komik karya Oto Suastika (Siauw Tik Kwie) dan juga wayang Wacinwa karya Gan Thwan Sing dari Museum Sonobodoyo sebagai acuan gambar. Tahap pertama perancang membuat sketsa gambar boneka Wacinwa seperti tampak dalam gambar 1.

Setelah perancang membuat sketsa gambar dalam kertas, kemudian gambar dituangkan dalam kulit kerbau, dan selanjutnya dilakukan pemahatan dan penyunggingan untuk menghasilkan tokoh wayang yang diinginkan. Dalam pembuatan boneka Wacinwa perancang dibantu oleh dua pemahat dari Desa Pucung, Wukirsari, Imogiri, Bantul bernama Siswanto dan Itukijan. Dalam hal pewarnaan wayang atau sunggingan perancang dibantu dua orang penyungging bernama Heri Sutapa dari desa Melikan Lor Bantul dan Wartono dari Desa Cabean, Sewon Bantul.

Dalam perancangan kali ini ukuran wayang tokoh-tokoh Wacinwa dibuat lebih tinggi dari boneka Wacinwa koleksi Museum Sonobudoyo yang mempunyai tinggi rata-rata sekitar $35 \mathrm{~cm}$, dan yang paling tinggi hanya sekitar $68 \mathrm{~cm}$. Ukuran tinggi replika boneka Wacinwa dibuat rata-rata sekitar $45 \mathrm{~cm}$ sampai $70 \mathrm{~cm}$. Konsep boneka Wacinwa karya Gan Thwan Sing yang berada di Museum Sonobudoyo kepala terlepas dengan badan, lengan dan tangan sangat pendak, serta tidak memakai palemahan. Dalam perancangan ini wayang selain dibuat lebih besar, semua kepala wayang dibuat menyatu dengan badan, bahu depan dan belakang wayang dibuat lebih panjang, serta semua diberi palemahan di antara kedua kaki tokoh. Hal ini dibuat dengan alasan supaya lebih mudah digerakkan dan wayang lebih jelas dilihat karena postur wayang lebih besar.

Adapun alasan pembuatan tokoh wayang dengan konsep kepala menjadi satu dengan badan, yaitu untuk mengurangi resiko kecelakaan dalam pertunjukan. Salah satu contoh kecelakaan dalam pertunjukan yaitu kepala terlepas dari badannya karena benang pengikat kepala nyangkut ke tokoh wayang lainnya. Jika terjadi demikian maka hal ini merupakan kecelakaan yang fatal

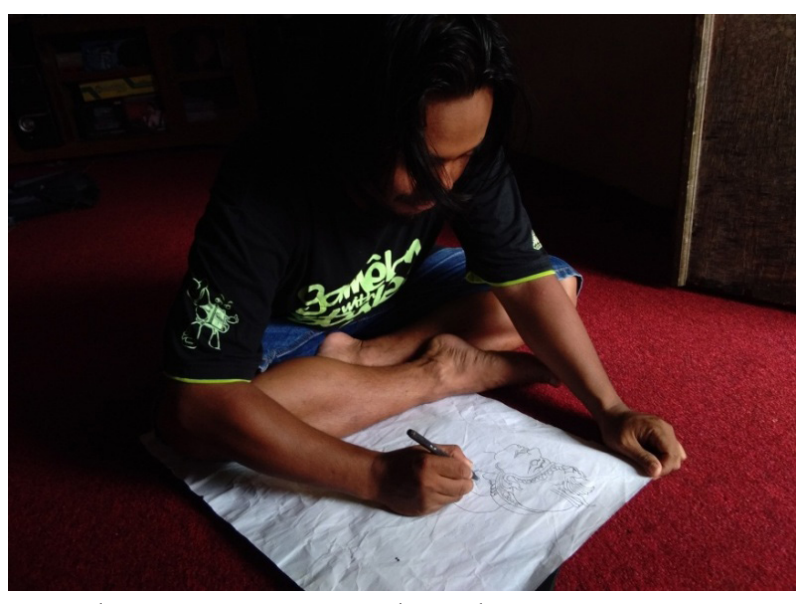

Gambar 1. Perancang membuat sketsa wayang wacinwa kedalam kertas. (Foto: Yuni, 2017) 
dalam pertunjukan. Konsep ini juga mempunyai manfaat lain yang tak kalah penting, yaitu lebih mudah untuk mengidentifikasi setiap karakter tokoh wayang. Muka atau wanda wayang dan busana atau asesoris wayang yang dihasilkan dalam perancangan ini, kiranya dapat menjadi ciri khusus dalam mengintrepertasikan tokoh satu dan lainnya.

\section{Interpretasi Bentuk Wayang Sie Jin Kwie dan Khai Sou Bun}

Telah dikatakan di awal bahwa pembuatan wayang didasarkan pada garap cerita kisah kejayaan Sie Jin Kwie yang diberi judul Sang Manggalayuda. Dua tokoh penting dalam cerita Sang Manggalayuda ini adalah Sie Jin Kwei dan Khai Sou Bun.

Sie Jin Kwei adalah tokoh yang mengawali karirnya sebagai prajurit dengan kesederhanaannya. Sie Jin Kwie terlahir sebagai anak dari seorang saudagar kaya yang bernama Sie Eng Yang. Setelah ayahnya meninggal, harta kekayaan orang tuanya dihabiskan semua untuk berguru ilmu kanuragan, sehingga ia jatuh miskin. Sie Jin Kwie menikahi Liu Kim Hoa. Pernikahan tersebut tidak mendapat restu dari ayah Liu Kim Hoa yang bernama Liu Wan Gwe. Oleh karena itu Sie Jin Kwei memutuskan untuk melamar menjadi seorang prajurit di kerajaan Tong. Berkat pusaka dari Dewi Kui Thian Hian yang berupa kitab Bu Ji Thian Si, ruyung Pek Ho Pian, busur Cin Thian Kiong, panah Coan In Chian, dan jubah Sui Ho Pou, Sie Jin Kwei selamat dari berbagai bahaya dan bisa menyelesaikan segala tugas yang diberikan dari kerajaan Tong. Dalam perjalanan karirnya, ia selalu dihalangi oleh penasehat yang bernama Tio Su Kui. Namun akhirnya sang raja mengetahui sendiri bahwa selama ini keberhasilan perang ke

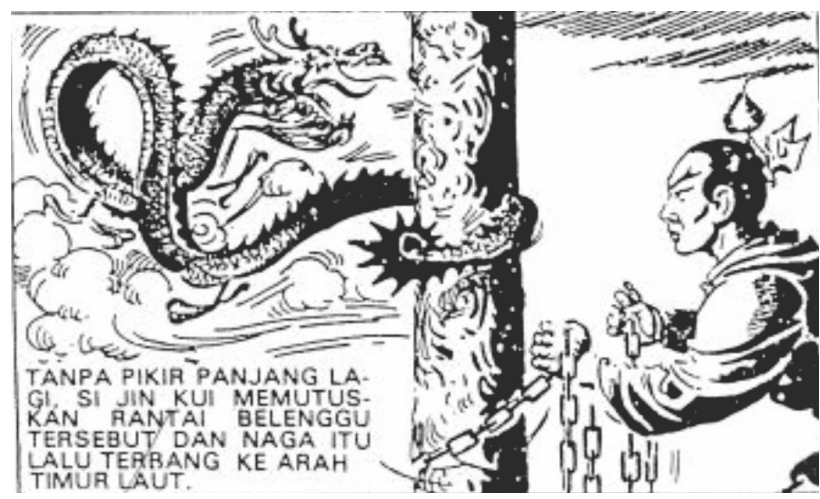

Gambar 2. Gambar Sie Jin Kwei melepaskan naga hijau dari belenggu (kiri) dan gambar Dewi Kui Thian Hian memberi

penjelasan kepada Sie Jin Kwei (kanan).
Timur adalah berkat pengorbanan Sie Jin Kwei. Keberhasilan Sie Jin Kwei yang membanggakan raja Tong Thai Cong yaitu ketika Sie Jin Kwie berhasil membunuh panglima besar Kolekok yang bernama Khai Sou Bun. Sang raja kemudian menobatkan Sie Jin Kwei menjadi Raja Muda Peng Lian Ong (Adipati Penentram Kolekok).

Musuh bebuyutan Sie Jin Kwei adalah Khai Sou Bun, seorang panglima tertinggi angkatan perang dari Negara Kolekok yang mempunyai kesaktian tinggi. Dalam setiap pertarungan, dia selalu dapat dikalahkan oleh Sie Jin Kwie, namun dia sulit dibunuh karena bisa menghilang. Dia mempunyai dendam yang sangat mendalam dengan Sie Jin Kwei. Hal ini dikarenakan Sie Jin Kwei adalah salah satu musuh yang mampu mengalahkan dan membunuh istrinya, Be Goat Eng. Khai Sou Bun bersumpah untuk menuntut balas terhadap Sie Jin Kwei atas kematian istrinya. Pada akhir pertarungannya dengan Sie Jin Kwei, Khai Sou Bun bunuh diri dengan memenggal kepalanya sendiri karena merasa selalu kalah dengan Sie Jin Kwei. Setelah kepala Khai Sou Bun terpenggal, tubuhnya berubah menjadi seekor naga hijau yang sangat besar dan akhirnya hilang terbang ke angkasa.

Dalam Komik Sie Djin Koei Tjeng Tang karya Oto Suastika kemunculan naga hijau dalam diri Khai Sou Bun tidak diceritakan secara jelas. Peristiwa yang menceritakan mengapa Khai Sou Bun bisa berubah menjadi seekor naga hijau juga tidak diceritakan dalam komik tersebut. Menurut perancang naga tersebut masih berkaitan dengan seekor naga yang pernah ditemui Sie Jin Kwei ketika hendak bertemu dengan Dewi Kui Thian Hian. Argumen ini didasarkan pada cerita dalam komik Sie Djin Koei Tjeng Tang karya Oto Suastika halaman 8 (lihat gambar 2).

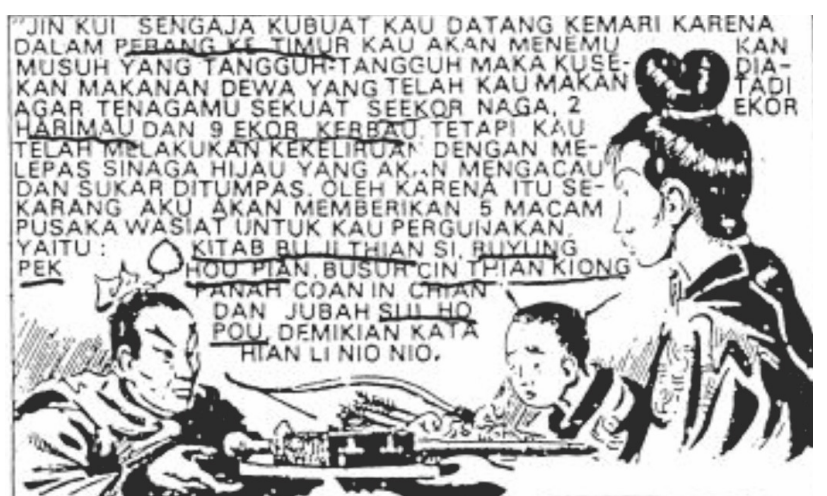


Dalam gambar 2 tersebut diceritakan bahwa sebelum bertemu dengan Dewi Kui Thian Hian, Sie Jin Kwei sempat bertemu dengan seekor naga yang sedang terbelenggu. Sang naga minta tolong kepada Sie Jin Kwei untuk melepaskannya dari belenggu tersebut dengan berkata: "Sie Jin Kwei. aku musuh lamamu, dan permusuhan kita akan aku akhiri jika kamu melepaskan aku dari belenggu ini". Setelah naga itu dilepaskan oleh Sie Jin Kwei, sang naga langsung pergi. Ketika bertemu dengan Dewi Kui Thian Hian, Sie Jin Kwei diberi penjelasan bahwa tindakan melepaskan naga tersebut adalah suatu kesalahan besar, karena naga hijau akan mengacau dan sukar ditumpas. Dalam gambar komik lain juga diceritakan arwah dari Khai Sou Bun yang terlihat seperti naga mengelabuhi Sie Jin Kwei sehingga hampir membunuh anaknya yang bernama Si Teng San.

Demikian tadi sepenggal kisah dua tokoh penting dalam perancangan ini. Dua tokoh tersebut dalam perancangan ini dibuat wayangnya dengan menginterpretasi karakter Sie Jin Kwie dan Khai Sou Bun koleksi Museum Sonobudoyo.

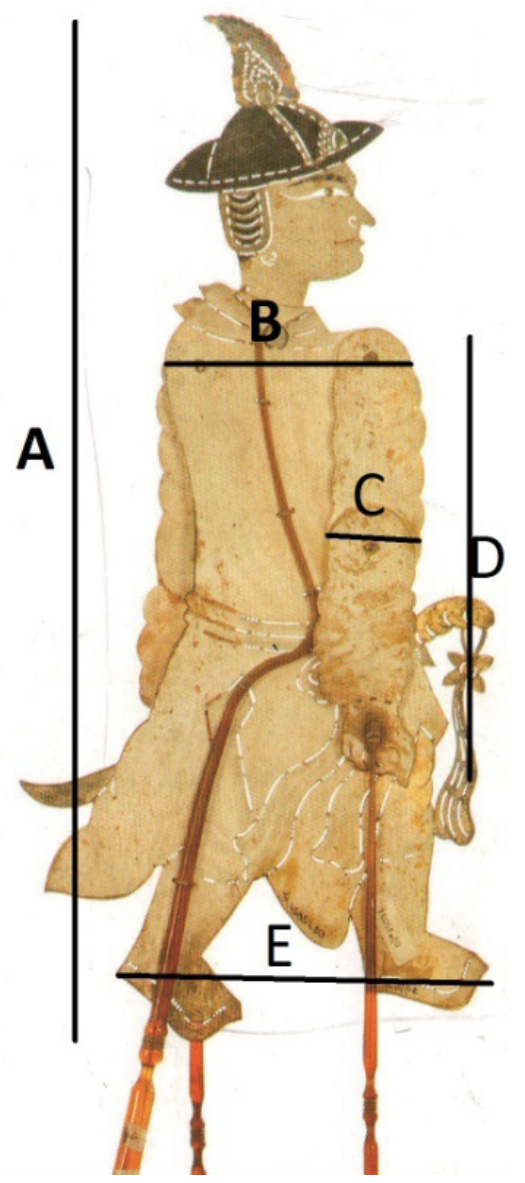

Gambar 3. Karakter Sie Jin Kwei koleksi Museum Sonobudoyo.
Sentral karakter dalam perancangan ini adalah tokoh Sie Jin Kwei. Tokoh wayang Sie Jin Kwei karya Gwan Tan Sing yang dimiliki Museum Sonobodoyo digambarkan sebagai seorang ksatria yang berkostum serba putih mulai dari baju, sepatu, ikat pinggang, dan lainnya. Tokoh ini bersenjatakan pedang dan berciri khas memakai topi layaknya seorang prajurit seperti tampak dalam gambar 3 .

Tinggi tokoh Sie Jin Kwei koleksi Museum Sonobudoyo $($ titik $A)=46 \mathrm{~cm}$, panjang bahu (titik $B)=10,5 \mathrm{~cm}$, panjang pergelangan tangan (titik C) $=3,5 \mathrm{~cm}$, panjang tangan $($ titik $\mathrm{D})=17 \mathrm{~cm}$, sedangkan panjang langkah kaki depan dan belakang $($ titik E $)=12 \mathrm{~cm}$. Dalam perancangan ini tokoh Sie Jin Kwei diinterpretasikan seperti tampak dalam gambar 4.

Tinggi tokoh Sie Jin Kwei karya perancang (titik A) $=55 \mathrm{~cm}$, panjang bahu (titik B) $=19 \mathrm{~cm}$, panjang pergelangan tangan (titik $C)=3,5 \mathrm{~cm}$, panjang tangan (titik D) $=25 \mathrm{~cm}$, sedangkan panjang langkah kaki depan dan belakang (titik E) $=19 \mathrm{~cm}$. Tokoh Sie Jin Kwei ini digambarkan sebagai tokoh yang sederhana tidak memakai banyak atribut ke-

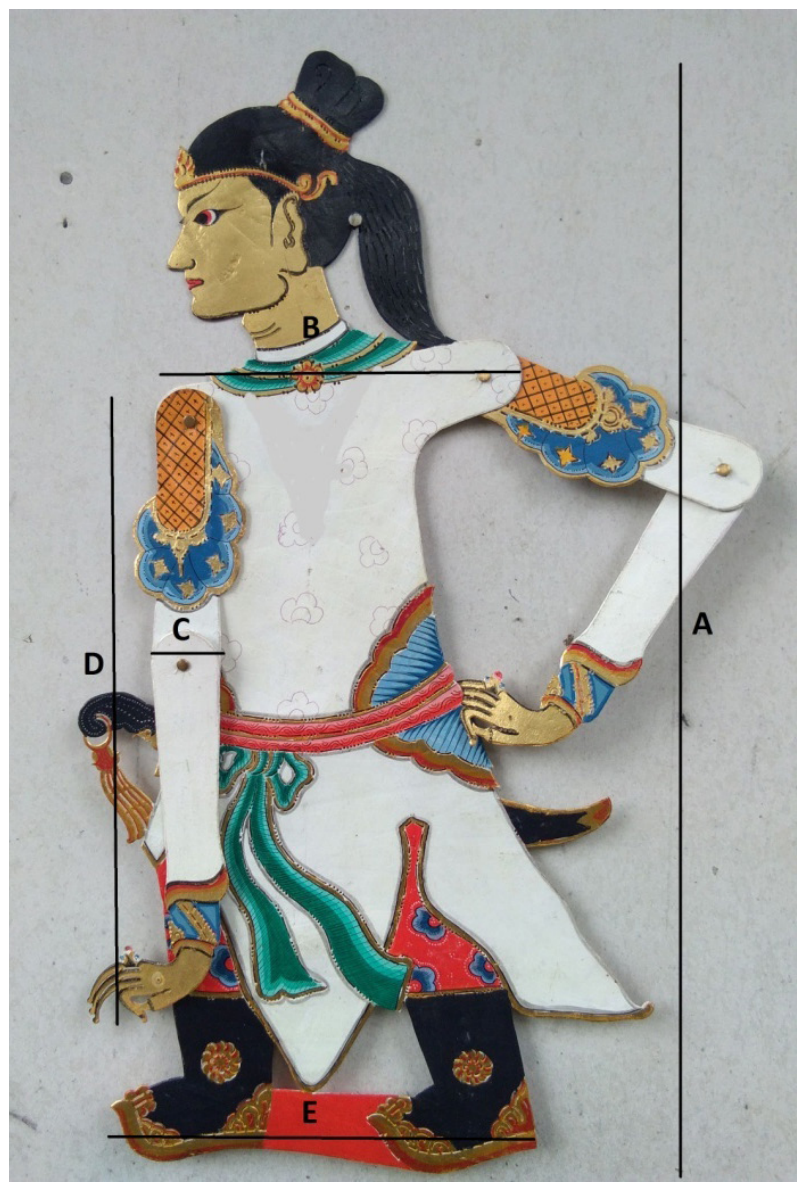

Gambar 4. Karakter Sie Jin Kwei kreasi perancang. (Foto: Aneng, 2017) 
prajuritan. Kepala memakai jamang dan memakai ikat rambut untuk menggelung rambutnya yang panjang, memakai asesoris keprajuritan seperti perisai lengan dan bersenjatakan pedang. Warna putih dalam tokoh ini hanya terletak pada baju sedangkan asesoris lainnya diberi pewarnaan seperti tokoh lainnya. Hal ini sengaja dilakukan supaya tidak terkesan membosankan, dan juga bila karakter dibuat semua warna putih akan berbenturan dengan warna kelir sehingga wayang jadi tidak jelas.

Dalam gambar komik dan bentuk asli boneka Wacinwa tokoh Sie Jin Kwei tidak memakai rambut. Namun dalam perancangan ini tokoh Sie Jin Kwei digambarkan memakai rambut dengan alasan secara kegunaan lebih menguatkan bahu tangan belakang dan akan mempermudah gerak tangan. Sebagai ciri khusus di atas kepala terselip bulu merak sesuai gambar tokoh Sie Jin Kwei dalam komik karya Oto Suastika (lihat gambar 6).

Karakter yang penting juga dalam perancangan ini ialah tokoh Khai Sou Bun. Marilah kita mulai dengan memperhatikan karakter tokoh Khai Sou Bun koleksi Museum Sonobudoyo seperti tampak dalam gambar 6 .

Tokoh Khai Sou Bun karya Gwan Tan Sing terbuat dari kulit kerbau dengan pahatan yang tidak jauh berbeda dengan motif pahatan wayang purwa. Perbedaan dengan wayang purwa terdapat pada asesoris atau busananya. Tinggi tokoh tersebut $($ titik $A)=44 \mathrm{~cm}$, panjang bahu (titik $B)=10,5$ $\mathrm{cm}$, panjang pergelangan tangan (titik $\mathrm{C})=3,5 \mathrm{~cm}$, panjang tangan (titik D) $=19 \mathrm{~cm}$, sedangkan panjang langkah kaki depan dan belakang (titik E)=19 $\mathrm{cm}$. Proporsi wayang tokoh Khai Sou Bun ini jauh berbeda dengan wayang kulit. Seorang dalang yang terbiasa memainkan wayang kulit purwa, dengan

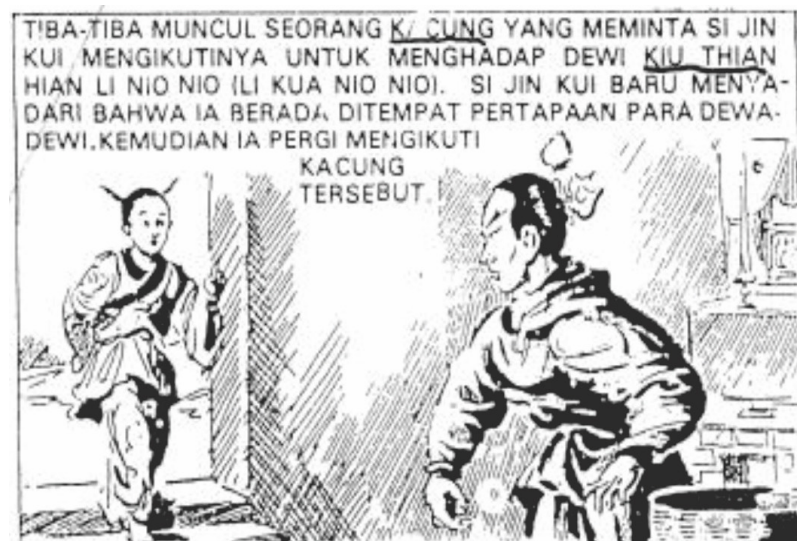

Gambar 5. Karakter Sie Jin Kwei (kanan) dalam cerita bergambar karya Oto Suastika. ukuran wayang yang demikian itu akan merasa kesulitan dalam menggerakkan wayang tersebut. Berdasarkan perhitungan itu maka perancang membuat tokoh Khai Sou Bun seperti tampak pada gambar 7 .

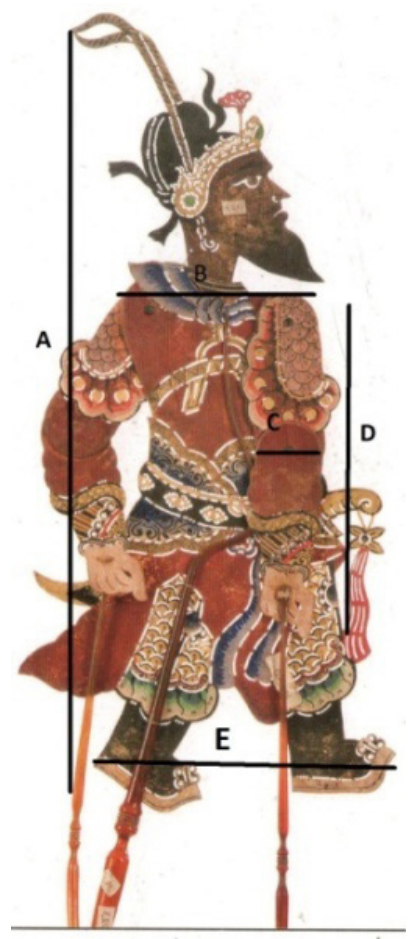

Gambar 6. Karakter Khai Sou Bun koleksi Museum Sonobudoyo.

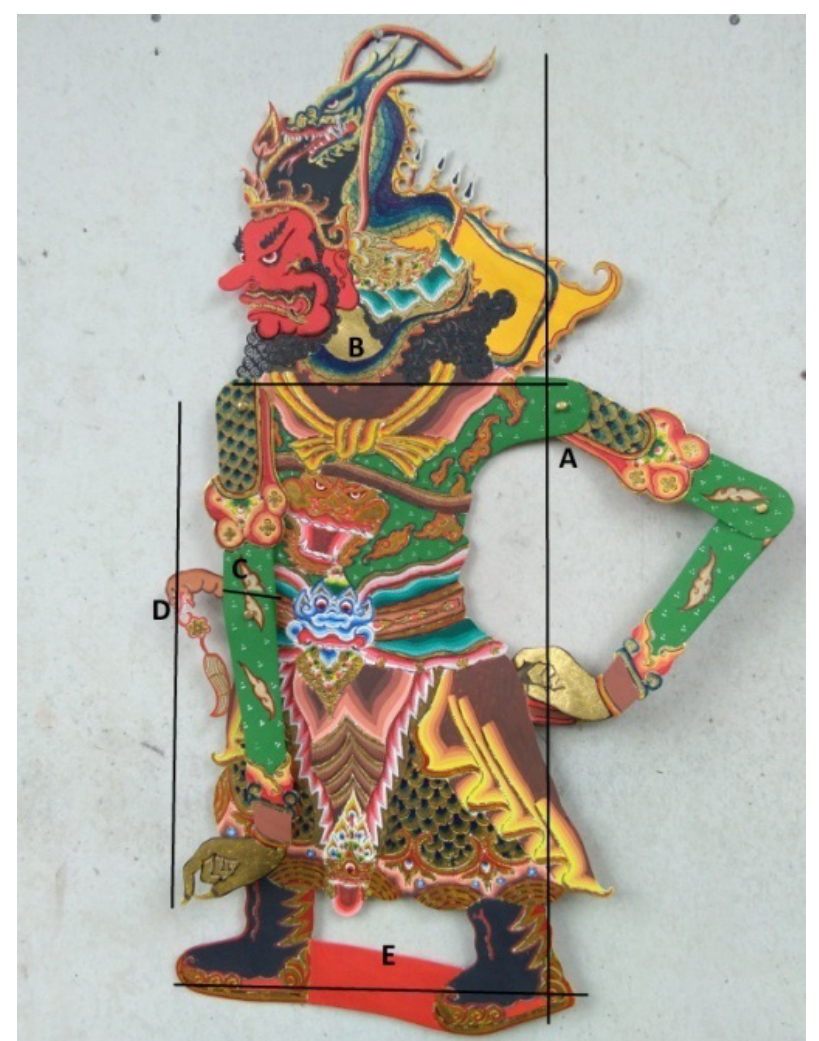

Gambar 7. Karakter Khai Sou Bun kreasi perancang. (Foto: Aneng, 2017) 
Tokoh Khai Sou Bun karya perancang ini terbuat dari kulit kerbau dipahat dan disungging. Proses penggarapannya tidak jauh berbeda dengan wayang purwa. Tinggi tokoh ini $($ titik $A)=65 \mathrm{~cm}$, panjang bahu (titik $B)=23 \mathrm{~cm}$, panjang pergelangan tangan (titik $C)=3,5 \mathrm{~cm}$, panjang tangan (titik D) $=33 \mathrm{~cm}$, sedangkan panjang langkah kaki depan dan belakang (titik E) $=26 \mathrm{~cm}$. Wanda atau muka tokoh ini dibuat menyerupai karakter raksaksa bertaring dan berwarna merah, kostum berwarna hijau dengan mahkota berlambang naga hijau, dan memakai bendera sebagai pusakanya. Tokoh ini dibuat dengan interpretasi karakter Khai Sou Bun sebagai seorang panglima besar negara Kolekok dengan tubuh besar dan kekar, memiliki sifat pendendam, pemarah, dan juga memiliki ilmu kanuragan yang sakti sekaligus sebagai inkarnasi atau titisan naga hijau. Jika dilihat dalam karakter wayang purwa, tokoh Khai Sou Bun ini senada dengan karakter tokoh Rahwana raja Alengka.

\section{Sie Jin Kwie dan Khai Sou Bun dalam Sang Manggalayuda}

Cerita ini diawali dengan adegan prolog yang mengisahkan perjalanan Sie Jin Kwei mendapatkan berbagai pusaka yang menjadi kekuatannya. Adapun adegan awal dari cerita Sang Manggalayuda dibuka dengan Sie Jin Kwei masuk ke dalam sebuah gua. Dalam keadaan yang gelap tiba-tiba muncul naga hijau yang sangat besar menyerang Sie Jin Kwei. Dalam pertarungan naga hijau dapat dibelenggu oleh Sie Jin Kwei. Ketika hendak dimusnahkan tiba-tiba naga hijau menghilang dan bersuara mengancam Sie Jin Kwei bahwa kelak akan menuntut balas. Sie Jin Kwei kemudian tidak sadarkan diri dan mendapat pertolongan Dewi Kui Thian Hian. Setelah disembuhkan Sie Jin Kwei diberi anugrah pusaka yang berupa kitab $\mathrm{Bu}$ Ji Thian Si, ruyung Pek Ho Pian, busur Cin Thian Kiong, panah Coan In Chian, dan jubah Sui Ho Pou. Setelah memberikan pusaka tersebut Dewi Kui Thian Hian pergi ke kahyangan.

Adegan kedua adalah raja Lie Si Bin mengutus Sie Jin Kwei untuk menaklukan kota Mo Thian Nia. Raja Lie Si Bin mendapat dukungan dari penasehat Ci Bou Kong, Jara muda Thai Ko Kim, dan Panglima Jendral Ut Ti Kiong untuk menaklukkan kota Mo Thin Nia salah satu kota
Negara Ko Le Kok yang kaya akan tambang emas. Dengan tujuan itu Lie Si Bin mengutus Sie Jin Kwei untuk menaklukkan kota tersebut. Sie Jin Kwei dengan penuh percaya diri menyanggupi dan bergegas melakukan titah Lie Si Bin.

Kepergian Sie Jin Kwei untuk menaklukkan kota Mo Thian Nia, diketahui oleh panglima Jendral Ko Le Kok yang bernama Khai Sou Bun. Dengan berkeinginan membunuh raja Tong Thai Cong, Khai Sou Bun segera menyerang Lie Sie Bin yang saat itu berada di kota Wat Hau Sia. Dalam penyerangannya ke kota Wat Hau Sia, Khai Sou Bun dibantu oleh seorang pendeta sakti bernama Bo Khak Thai. Mendengar penyerangan oleh Khai So Bun, Lie Si Bin terkejut dan mengerahkan tentaranya untuk menghadangnya. Namun tak satupun panglima yang berhasil mengalahkan kekuatan Khai So Bun dan pendeta Bo Khak Thai. Jendral Ut Ti Kiong yang paling kuat di Tong Thai Cong juga tidak mampu mengalahkannya. Akhirnya kota Wat Hau Sia terkepung tentara Khai Sou Bun.

Setelah mendapat nasehat dari Ji Bau Kong, Lie Si Bin memerintahkan raja muda Thai Ko Kim untuk memanggil Sie Jin Kwei kembali dari kota Mo Thian Nia. Mendapat titah Lie Si Bin, Thai Ko Kim segera berangkat ke Mo Thian Nia. Dengan kecerdikan yang dia miliki, Thai Ko Kim mampu menerobos barisan Khai So Bun dengan selamat. Setibanya Thai Ko Kim di Mo Thian Nia, ternyata Sie Jin Kwei sudah berhasil merebut kota Mo Thian Nia dengan mengalahkan jendral Ko Le Kok yang bernama Ang Ba Ban. Thai Ko Kim gembira melihat keberhasilan Sie Jin Kwei dan segera memerintahkan Sie Jin Kwei kembali untuk menolong raja Lie Si Bin dari kepungan Khai So Bun.

Setibanya Sie Jin Kwei di What Hou Sia pertempuran dasyat terjadi antara tentara Sie Jin Kwei dan pasukan Khai So Bun. Sie Jin Kwei hampir mati karena terkena senjata Bo Khak Thai yang berupa batu-batu api yang berbisa. Namun berkat bantuan dewi Li Ceng, Sie Jin Kwei sembuh kembali. Mendengar cerita Sie Jin Kwei tentang pendeta Bo Khak Thai akhirnya dewi Li Ceng tergerak membantu dalam peperangan. Di dalam pertempuran, Bo Khak Thai dibuat tak berdaya oleh dewa Li Ceng. Akhirnya dengan kesaktian dewi Li Ceng, Bo Khak Thai berubah menjadi 
seekor kura-kura besar dan dibawanya kembali ke kahyangan. Melihat Bo Khak Thai adalah jelmaan seekor kura-kura Khai Sou Bun terkejut dan hendak melarikan diri, namun tetap dikejar oleh Sie Jin Kwei. Setelah dikepung oleh Sie Jin Kwei akhirnya mereka berperang. Dalam peperangan itu akhirnya Khai Sou Bun kalah dan terbunuh.

Lie Sie Bin sangat berterima kasih kepada Sie Jin Kwei. Atas jasanya kepada Tong Thai Cong, Sie Jin Kwei diangkat menjadi Raja Muda Peng Lian Ong atau disebut Adipati Penentram Kolekok.

\section{Penutup}

Pekeliran Wacinwa pernah hidup dan berkembang di daerah Yogyakarta dan sekitarnya. Wayang yang lahir pada tahun 1925 oleh Gan Thwan Sing ini sempat mencapai ketenarannya sekitar tahun 1930 yang persebarannya meluas tidak hanya di Yogyakarta tetapi di luar kota Yogyakarta bahkan merambah kota-kota besar seperti Semarang, Bandung, dan Surabaya. Setelah Gan Thwan Sing meninggal di tahun 1967 wayang sudah jarang muncul bahkan sudah tidak ada lagi pertunjukannya (Soelarto dan Albiladiyah, 1980: 15-16).

Boneka Wacinwa koleksi Museum Sonobudoyo terlalu kecil, kepalanya terlepas dari badan, dan sulit digerakkan. Menurut perancang hal ini menjadi salah satu faktor kendala Wacinwa kurang berkembang di masyarakat. Selain itu boneka Wacinwa hanya dimiliki oleh Museum Sonobudoyo. Hal ini menyebabkan setiap kali ada pementasan Wacinwa harus meminjam wayang. Kendala dalam pengadaan wayang dan peminjaman wayang ini membuat pakeliran Wacinwa sulit berkembang.

Kendala-kendala seperti disebutkan di atas menarik perhatian dan minat perancang untuk mengembangkan Wacinwa. Perancang kemudian memberanikan diri membuat konsep-konsep boneka tokoh Wacinwa yang baru, yang dalam pembuatannya terinspirasi dari karya yang sudah ada. Dalam pembuatan tokoh-tokoh tersebut, perancang menawarkan bentuk wayang Wacinwa yang berpostur lebih tinggi, bahu tangan lebih panjang, tangan lebih panjang, memakai palemahan, dan bentuk wayang yang disesuaikan dengan konsep dan kepentingan perancang. Selain menawarkan tokoh-tokoh Wacinwa baru, dalam perancangan ini perancang juga menawarkan garap sanggit lakon baru dengan judul Sang Manggalayuda.

\section{Kepustakaan}

Mastuti, Dwi Woro Retno. 2008. Deskripsi Wayang Kulit Cina - Jawa Koleksi Dr. Walter Angst Uberlingen, Jerman [Laporan Penelitian]. Jakarta: DAAD.

Prasetya, Hanggar Budi. 2014. "Wacinwa: Silang Budaya Cina-Jawa di Yogyakarta" dalam Katalog Pameran Wayang Cina Jawa koleksi Museum Negeri Sonobudoyo Yogyakarta. Yogyakarta: Musem Negeri Sonobudoyo . 2014. "Reconstruction of Chinese-Javanese Shadow Puppet Theatre" dipresentasikan dalam The 10 th International Conference on Southeast Asian.

Soelarto, B dan Ilmi Albiladiyah.1980. Wayang Kulit Cina-Jawa Yogyakarta. Jakarta: Proyek Media Kebudayaan Depdikbud.

Kwie, Siaw Tik. 1983. Komik Sie Djin Koei Tjeng Tang. Jakarta: Gabungan Tridarma Indonesia 1984. Komik Sie Djin Koei Tjeng See. Jakarta: Zambhalar

Untoro, Ons. 2014. "Wayang Kulit Cina-Jawa, Silang Identitas Antara Cina dan Jawa" dalam Katalog Pameran Wayang Cina Jawa koleksi Museum Negeri Sonobudoyo Yogyakarta. Yogyakarta: Museum Negeri Sonobudoyo. 